\title{
Anticancer Potential of Ficus religiosa (Linn) Against Human Breast Cancer Cell Line MDA-MB- 231 and its Phytoconstituents by HR-LCMS
}

Ayesha Shaikh ( $\nabla$ shaikhayesha817@gmail.com )

Dr Babasaheb Ambedkar Marathwada University

Muftedar Patel

Wockhardt Research Centre

Manohar Padul

Dr Babasaheb Ambedkar Marathwada University

\section{Research}

Keywords: F. religiosa, SRB, HR-LCMS, MDA-MB-231, Anticancer, Secondary Metabolites

Posted Date: December 22nd, 2020

DOl: https://doi.org/10.21203/rs.3.rs-132206/v1

License: (c) (i) This work is licensed under a Creative Commons Attribution 4.0 International License.

Read Full License 


\section{Abstract}

Background: Ficus religiosa is widely present in India especially in northern region and has been traditionally used for various indications. We investigated the anticancer potential of leaf extract against human breast cancer cell line MDA-MB-231. The anticancer potential was further supported by identifying potential phytoconstituents of the extract by HR-LCMS analysis.

Methods: Amongst the collected fractions, subfraction of chloroform was selected for anticancer screening in parallel for identification of phytochemicals by using HR-LCMS. Extract showed positive results in a battery of two tests employed in the current study by using MDA-MB231 breast cancer cell lines. In trypan blue exclusion dye test, $50 \%$ of cell killing was observed at $110 \mu \mathrm{g} / \mathrm{ML}$. In vitro anticancer activity by using SRB assay showed dose dependent growth inhibition at $62.5,125,250$ and $500 \mu \mathrm{g} / \mathrm{mL}$ concentrations. The parameters $\mathrm{LC}_{50}, \mathrm{GI}$ and $\mathrm{TGI}_{50}$ found from the assay were $100,200,300 \mu \mathrm{g} / \mathrm{mL}$ respectively. Assay parameter In case of HR-LCMS analysis several active phytochemicals were identified in the extract.

Results: F. religiosa leaf extract showed promising anticancer activity against human breast cancer cell MDA-MB-231.

Conclusion: F. religiosa leaf extract has promising anticancer potential against human breast cancer cells MDA-MB-231 and numerous phytochemicals further warrants evaluating it for multi-therapeutic potential.

\section{Background}

Nowadays, cancer is considered as one of the most dominant and progressive diseases in the world due to which morbidity and mortality is considered to be very high in records. The disease, not only deteriorate quality of life but also putting high economic burden globally. Treatment and prevention of this disease is necessary by inventing new treatment strategies, economic models, and innovative drugs. Herbal medicines block critical biochemical pathways converting normal cells to cancer cells and check the progress of the disease [1]. Cancer disease starts with the deformation of a natural cell caused by genetic mutations in DNA [2]. Cancer is an important health problem in developing and developed countries. Cancer is the second leading causes of death worldwide (WHO). The most important problem in cancer treatment is destroying cancerous cells in parallel by protecting body's own normal cells. In order to bring anticancer medicines from natural resources like plants, cytotoxicity testing of compounds and safety screening the raw extracts of plants are essential [3]. Medicinal herbs are valuable assets in making anticancer strategies due to having multiple chemical compounds, secondary metabolites of potential to fight against the disease [4]. Plants produce a wide range of chemical compounds called secondary metabolites; they have no direct role in the growth of plant. Alkaloids, terpenoids, flavonoids, pigments, and tannins are important constituents of these compounds. Secondary metabolites exhibit biological effects like anti-inflammatory, anticancer and contraceptive etc [5]. Many studies reported that treatment 
of cancer with herbal products stand as one of the safe treatments because of no side effects on body's healthy cells [1].

Ficus religiosa (L.) is a huge evergreen tree found throughout India. It is wild as well as cultivated. Commonly known as 'Peepal tree' is a large widely branched tree with leathery, heart shaped, long tipped leaves on long slender petioles and purple fruits growing in pairs [6]. Phytochemical investigation of Ficus religiosa (L.) leaves showed campestrol, stigmasterol, isofucosterol, a-amyrin, lupeol, tannic acid, arginine, serine, aspartic acid, glycine, threonine, alanine, proline, tryptophan, tryosine, methionine, valine, isoleucine, leucine, n-nonacosane, n-hentricontanen, hexa-cosanol and n-octacosan [7]. The extract also demonstrated good anti-iflammatory and wound healing potential in experimental burn model $[8,9]$. Traditionally used in breast cancer cell lines, induces apoptosis [10]. In Asian countries, F. religiosa (L.) bark is used for treating various diseases like cervical cancer, epilepsy and inflammation [11]. F. religiosa (L.) barks, leaves and fruits are used in various treatments, such as diabetes, skin diseases, ulcers, dysentry, diarrohoea, stomachache, anti-inflammatory, antioxidant and anticancer agent [12]. Traditional herbal practice in the cancer is passed from one generation to the other through oral tradition. Ficus religiosa (L.) leaves and fruits are used for treatment of cancer in Chhattisgarh (India) [13].

Some species of the genus Ficus shows anticancer effects and have been evaluated in vitro by employing different cancer cell lines. Ficus carica leaves and fruits have been studied to define anticancer effects on liver cell line Hu7it. The extracts showed effect but at very high concentrations [14]. Leaf extract of Ficus carica decreased proliferation of MDA-MB-231 and induced apoptotic events [15]. Crude extracts of leaves, fig and stem bark from Ficus exasperata demonstrated good activity against ovarian cancer cells A2780 in vitro [16]. MDA-MB-231 is breast cancer cell line displays invasiveness by mediating the proteolytic degradation of the extracellular matrix (ECM), including basement membrane and several mechanical barriers to the ECM, through the increased expression of matrix metallo proteinases. It is perfect model for screening of chemotherapeutic agents because it is highly aggressive and differentiated triple-negative breast cancer cell line. It lacks oestrogen receptor and progesterone receptor expression, as well as human epidermal growth factor receptor 2 amplification $[17,18]$.

\section{Material And Method}

\section{Chemicals, reagents and equipment}

All the chemicals used in the experiment were of high quality and analytical grade. The chemicals procured for the experiment were methanol, ethyl acetate, hexane, chloroform, ethanol, acetone, $0.4 \%$ Trypan Blue dye solution (Sigma), Sulforhodamine B (SRB) solution, DMSO (Dimethyl sulphoxide), microscope (Carl Zeiss) and haemocytometer. Human breast cancer cells were maintained and all in vitro experiments were conducted at was conducted at ACTREC, Mumbai.

Plant material collection and preparation of powder 
The mature leaves of Ficus religiosa (L.) were collected from the campus of Dr. Babasaheb Ambedkar Marathwada University, Aurangabad Maharashtra, India in summer 2017 herbarium deposited in Department of Botany, Accession no. 0710. This plant validated taxonomically Sp. PI. 1059 1753. The details are also found in (IPNI Life Sciences Identifier (LSID) urn:Isid:ipni.org:names:853563-1) Leaves were thoroughly washed with distilled water and completely dried at room temperature. Dried leaves were crushed to make fine powder by using mixer grinder.

Extraction and fractionation of $F$. religiosa by column chromatography

Fine dried powder ( $250 \mathrm{gm}$ ) was sequentially soaked in non-polar to polar solvent as mentioned above in n-hexane, chloroform, ethyl acetate and methanol (1:10 w/v) for preliminary fractionation. Subsequently, next fractionation was carried out at room temperature (around $30^{\circ} \mathrm{C}$ ) for 12 hours with intermittent shaking of extraction flask and finally filtered through with whatman filter paper (Whatman no. 41). Resulting extracts were $\mathrm{n}$-hexane, chloroform, ethyl acetate and methanol. Chloroform extract was evaporated to dryness and the resulting weight of extract was $3.2 \mathrm{gm}$ (sticky and brown colour). This extract was subjected to column chromatography using silica gel of 120-160 mesh. Hexane and ethyl acetate were used for elution in different ratio (2:8 (A), 4:6 (B), 6:4 (C), 8:2 (D and 10:0 (E) v/v). Each $20 \mathrm{ml}$ fractions were collected at room temperature and were stored at $4{ }^{\circ} \mathrm{C}$ for further use.

Cell culture

The MDA-MB-231 cell lines were maintained in Dulbecco's Modified Eagle Medium (DMEM, GIBCO) supplemented with $10 \%$ heat inactivated foetal bovine serum, FBS (GIBCO) and antibiotics $(100 \mathrm{U} / \mathrm{ml}$ penicillin and $100 \mathrm{\mu g} / \mathrm{ml}$ streptomycin). Cultures were maintained at $37^{\circ} \mathrm{C}$ in $5 \% \mathrm{CO}_{2}$ and $95 \%$ humidified atmosphere. Confluent cells were trypsinized and then subcultured at lower numbers in new culture flasks for experiment.

In vitro cytotoxicity of $F$. religiosa extract in MDA-MB-231 cell line

The cytotoxic concentrations of $F$. religiosa leaf extract were determined by employing Trypan Blue dye exclusion assay. The cells were grown in a 96-well plate at a density of $3 \times 10^{3}$ cells per well. After incubation for $24 \mathrm{~h}$, the cells were washed and treated with extract concentrations of 125, 250, 500 and $1000 \mu \mathrm{g} / \mathrm{mL}$ and further incubated for $48 \mathrm{~h}$. Monolayer and floated cells were mixed in the well to make uniform cell suspension. Later cell suspension was added by equal amount of $0.4 \%$ Trypan Blue dye solution, mixed and taken on haemocytometer slide for counting of live and dead cells. From each concentration, live (colourless) and dead cells (blue coloured) were differentiated and counted to calculate \% live cells (Table 2). The percentage of viable cells was calculated by dividing the number of viable cells by the number of total cells and multiplying by 100 or \% viable cells $=[1-($ Number of blue cells $\div$ Number of total cells) $] \times 100$. Cytotoxic concentration $\left(\mathrm{CC}_{50}\right)$ was determined by using $\%$ viable cells data obtained at various concentrations by feeding in statistical analysis [19]. 
In vitro anticancer activity of $F$. religiosa extract in MDA-MB-231 cell line

Exponentially growing cells were confirmed and prepared cell suspension in DMEM at the densities of $3 \times$ $10^{3}$ in $100 \mu \mathrm{L}$. In a 96 well plate, $100 \mu \mathrm{L}$ of cell suspension was seeded in each well and incubated at $37^{0}$ C, $5 \% \mathrm{CO}_{2}$ and $95 \%$ humidity for 24 hours. Next day before addition of test substance monolayer of the cells was washed prior to addition of experimental substance. $5 \mathrm{mg}$ of dried leaves extract was weighed in microfuge tube and about 500 uL of DMSO (Dimethyl sulphoxide) was added and extract was completely solubilised by vortex mixing. Final volume was adjusted to $5 \mathrm{~mL}$ by adding sterile water for injection to become final strength of $1 \mathrm{mg} / \mathrm{mL}(1000 \mu \mathrm{g} / \mathrm{mL})$ of dried sample extract. The strength of $1000 \mu \mathrm{g} / \mathrm{mL}$ was further diluted to prepare the concentrations of $25,50,100$ and $200 \mu \mathrm{g} / \mathrm{mL}$ by adding sterile water for injection. Aliquots of $10 \mu \mathrm{L}$ of all 4 dilutions of the samples were added to the wells already containing $90 \mu \mathrm{L}$ of medium, resulting in the required final concentrations in an ascending order of 25, 50, 100 and $200 \mu \mathrm{g} / \mathrm{mL}$ exposed to the breast cancer cell line (Table 3). Standard drug Adriamycin was kept as positive control along with the test substance at the concentrations of 10, 20, 40 and $80 \mu \mathrm{g} / \mathrm{mL}$ in the same pattern (Fig. 1). After addition of substances, plates were incubated at standard conditions for 48 hours and assay was terminated by the addition of cold TCA. Cells were fixed in situ by the gentle addition of $50 \mu \mathrm{l}$ of cold $30 \%$ (w/v) TCA (final concentration, 10\% TCA) and incubated for 60 minutes at $4{ }^{\circ} \mathrm{C}$. The supernatant was discarded; the plates were washed five times with tap water and air dried. Sulforhodamine B (SRB) solution $(50 \mu \mathrm{l})$ at $0.4 \%(\mathrm{w} / \mathrm{v})$ in $1 \%$ acetic acid was added to each of the wells, and plates were incubated for 20 minutes at room temperature. After staining, unbound dye was recovered and the residual dye was removed by washing five times with $1 \%$ acetic acid. The plates were air dried. Bound stain was subsequently eluted with $10 \mathrm{mM}$ trizma base, and the absorbance was read on plate reader at a wavelength of $540 \mathrm{~nm}$ with $690 \mathrm{~nm}$ reference wavelength. During the treatment, standard environmental conditions were maintained till end of the treatment. There were three replicates of the experiment were performed at all the selected concentrations from sample and standard drug and average data was calculated and presented. This experiment was conducted at ACTREC Mumbai, India.

\section{Statistical analysis}

For cytotoxicity experiment, data of three independent experiments were evaluated and presented as mean and $\pm \mathrm{SD}$. The $\mathrm{CC}_{50}$ in $\mu \mathrm{g} / \mathrm{mL}$ of the extract was determined from three run of the experiment and presented as mean. For SRB assay, percent growth was calculated on the basis for test wells relative to control wells. Percent cell growth of extract was expressed as the ratio of average absorbance of the test well to the average absorbance of the control wells $\times 100 . \%$ Cell growth $=$ Average absorbance of extract/Average absorbance in controlx 100 . Using six absorbance measurements [time zero (Tz), control growth (C), and test growth in the presence of the extract at the four concentration levels ( $\mathrm{Ti}$ ), the percentage growth was calculated at each of the test sample concentration levels. Percentage growth 
inhibition was calculated as $[\mathrm{Ti} / \mathrm{C}] \times 100 \%[20,21]$. Using Finney's method of probit analysis, $\mathrm{CC}_{50}$ and $50 \%$ affected growth was determined from average values of 3 experiments [22].

Identification of phytoconstituents from leaves extract of $F$. religiosa by HR-LCMS

Metabolites were identified from subfraction of chloroform extract was carried out at Sophisticated Analytical Instrument Facility (SAIF), Indian Institute of Technology, Bombay. Samples were analyzed on an LC-ESI-Q-TOF-MS (Agilent Technologies G6550A) system equipped with a G4220B pump, G4226A auto sampler and $\mathrm{G} 1316 \mathrm{C}$, and a diode array detector. The elution solvent consisted of a gradient system of $0.1 \%$ formic acid in water $(A)$ and acetonitrile $(B)$ at a flow rate of $0.2 \mathrm{ml} / \mathrm{min}$. The gradient system started with 95:5\% A: B reaching 5:95\% A:B in 30 min, then back to the initial composition 15 min, which was held at the same composition for $2 \mathrm{~min}$. The MS analysis was carried out using an ESI-positive ionization mode. MS source conditions were as follows: capillary voltage 3,500 V; gas temperature, $250^{\circ} \mathrm{C}$; drying gas flow, $13 \mathrm{~L} / \mathrm{min}$; sheath gas temperature, $300^{\circ} \mathrm{C}$; sheath gas flow, 11 ; nebulizing gas pressure, 35 (psig); fragmentor, $175 \mathrm{~V}$; skimmer, $65 \mathrm{~V}$; Octopole RF Peak, $750 \mathrm{~V}$; and mass range m/z 501,000. The resolution was 40,000 FWHM. The Metlin database was used for structure confirmation [23].

\section{Result}

In-vitro cytotoxicity

Cytotoxicity was determined by counting number of dead cells present among the total counted cells on Neubauer chamber and expressed in \% dead cells at respective concentrations. The percent dead cells found were $5 \%, 12 \%, 18 \%$ and $25 \%$ at the concentrations of $125,250,500$ and $1000 \mu \mathrm{g} / \mathrm{mL}$ respectively after incubation with the extract. Extract found mild cytotoxic at highest selected concentration of $1000 \mu \mathrm{g} / \mathrm{mL}$. The calculated $\mathrm{CC}_{50}$ value was found $4944.772 \mu \mathrm{g} / \mathrm{mL}$ by considering $\%$ dead cells at respective concentrations.

In-vitro activity of $F$. religiosa leaves extract in MDA-MB-231 breast cancer cell lines by using SRB assay

Determination of in-vitro anticancer activity of leaves extract was done by using human breast cancer cell line MDA-MB-231. Growth inhibition of treated cells was investigated by performing three experiments and \% control growth of treated cells against untreated cell growth. Percent control growth in Experiments 1 was found to be $97.1,96.2,70.2$ and 19.6 at $25,50,100$ and $200 \mu \mathrm{g} / \mathrm{mL}$ concentrations respectively. Percent control growth in Experiment 2 was found to be 103.4, 97.9, 74.9 and 25.5 at 25, 50, 100 and $200 \mu \mathrm{g} / \mathrm{mL}$ concentrations respectively. Percent control growth in Experiment 3 was found to be 97.9, 93.6, 74.4 and 19.5 at 25, 50, 100 and $200 \mu \mathrm{g} / \mathrm{ml}$ concentrations respectively. Average \% control growth of 3 experiments was $99.4,95.9,73.1$ and 21.5 in $25,50,100$ and $200 \mu \mathrm{g} / \mathrm{mL}$ concentrations respectively (Table 4). It was observed that leaves extract at the concentrations of 100 and $200 \mu \mathrm{g} / \mathrm{mL}$ caused significant retardation of cell growth in 48 hours of incubation as compared to growth of untreated cells. In Adriamycin treated arm, there was no growth observed in all the selected concentrations, the \% growth values were found negative due to high rate of cytotoxicity without growth of the cells occurred up to 48 
hours of incubation. Hence, results of Adriamycin validate the experimental set-up and its anticancer potential on MDA-MB-31 cell lines. From above parameters, lethal concentration and total inhibition of the cells were calculated. The concentration of $180 \mu \mathrm{g} / \mathrm{mL}$ of leaves extract caused $50 \%$ lethality of the cells $\left(\mathrm{LC}_{50}\right)$, whereas total growth inhibition of the cells occurred at the concentration of $120 \mu \mathrm{g} / \mathrm{mL}$ and the $50 \%$ inhibition of the cell growth $\left(\mathrm{GI}_{50}\right.$ ) was found to be at the concentration of $70 \mu \mathrm{g} / \mathrm{mL}$ (Table 5). Average \% control affected growth was calculated as 100-\% control growth values i.e. 0.6, 4.1, 26.9 and $78.5 \%$ at the concentrations of $25,50,100$ and $200 \mu \mathrm{g} / \mathrm{mL}$, respectively. On the basis of these values, $50 \%$ affected growth was found at $130.503 \mu \mathrm{g} / \mathrm{mL}$ (with the confidence interval of (51.489 to $330.774 \mu \mathrm{g} / \mathrm{mL}$ ). Breast cancer cells in 48 hours of treatment with leaves extract sample showed reduced density and morphology of cells as compared to control. Overall, the results of the study indicated that the growth inhibition and killing potential of the extract occurred at higher concentrations (Fig. 2, 3.1 and 3.2). Standard drug, Adriamycin showed satisfactory results at selected concentration, which confirms the validity of experiment. Due to absent of growth proteins of the cells from the lowest concentration of $10 \mu \mathrm{g} / \mathrm{mL}$ of Adriamycin, $\mathrm{TGI}$ and $\mathrm{GI}_{50}$ parameters were found to be $<10 \mu \mathrm{g} / \mathrm{mL}$ and $\%$ control growth values were found negative. Cell growth after 48 hours of Adriamycin treatment showed reduced density (Fig. 2, 3.1 and 3.2).

F. religiosa leaves extraction and identification of phytochemicals

Fine dried powder was sequentially soaked in non-polar to polar solvents. Among all extractions the chloroform extract was further fractionated by column chromatography using n-hexane and ethyl acetate. In this study, total 100 compounds, including Convallatoxin, Umbelliferone, Embelin, Dihydrocoumarin, Fendiline, Hydroxyibuprofen (Table 1) were detected in the chloroform extract of $F$. religiosa (L.) leaves as active compounds by HR-LCMS. The above work was done at IIT, Mumbai, India.

\section{Convallatoxin}

Convallatoxin is natural glycoside found in many organisms, including plants. This substance is reported as inhibitor of cancer cell growth [24]. It is also reported as effective anti-proliferative agent against some cancer types $[25,26]$. In another study, it is demonstrated good activity against colorectal type of cancer [27]. It also exerts good cytotoxic effects against ER ${ }^{+}$breast cancer cell lines, MCF-7 cells [25]. (Fig. 4A).

Umbelliferone

Umbelliferone is a phenylpropanoid and it is coumarin and widely spread in plants28. Umbelliferone has found as antioxidant in the literature [29]. It is used as a sunscreen agent and as optical brightener in textiles [30]. It has anti-inflammatory [31], anti-diabetic [32] and anti-tumour activity [33]. Umbelliferone also have glycation inhibitory activity [34], angiotensin converting enzyme inhibitory activity [35]. Antinociceptive [36], antimicrobial [37], neuroprotective [38], hepatoprotective [39], anti-inflammatory and pro apoptotic effects in colon carcinogenesis [40]. (Fig. 4B) 
Embelin is naturally occurring parabenzoquinone isolated from plant sources. It inhibits cell growth, induces apoptosis, and activates caspase-9 in prostate cancer cells with high levels of inhibitor of apoptosis family of proteins called XIAP, but has a minimal effect on normal prostate epithelial and fibroblast cells with low levels of XIAP [41]. It is used for treating various ailments like chronic inflammatory disorders, heart and urinary conditions, snake and insect bites, and tumour [42]. Embelin would be useful as an adjunct therapy for cerebral stroke and as a potent neuroprotective agent [43]. It possesses all the characteristics of a compound which can cross the blood-brain barrier and elicit an effect on the CNS [44]. Embelin is reported for its CNS effect by diverse mechanisms. (Fig. 4C).

Dihydrocoumarin

Coumarins are natural and synthetically active components used for various pharmacological actions. It is widely useful in various types of medicinal treatments, such as cancer, inflammation, infection, and enzyme inhibition [45]. Dihydrocoumarin (DHC) is an inhibitor of the Sirtuin family of NAD ${ }^{+}$-dependent deacetylases [46] 4-arylcoumarins and 3, 4-dihydro-4-arylcoumarins were synthesized and tested for antioxidant activity, antitumor activity [47]. 3, 4-Dihydrocoumarins, considered to be valuable building blocks, have attracted considerable attention due to their various biological activities [48] such as aldose reductase inhibition [49], protein kinases [50] antiherpetic and flavouring agent to a diverse set of foods for example- soft drinks, yogurt, muffins) [51]. In addition, the 3,4dihydrocoumarin scaffold has been discovered in a number of important natural compounds as exemplified by Calomelanol A-C, E-J [52]. (Fig. 4D).

Fendiline

Fendiline inhibits cancer cell proliferation, specifically cells expressing mutant K-Ras, by altering K-Ras cellular distribution and downstream signalling [53]. It inhibits the maintenance and expression of methamphetamine [54]. The effects of Fendiline were produced in the absence of aversive or rewarding properties and without significant impairment on motivated motor behaviour [55]. It was primarily developed as L-type $\mathrm{Ca}_{2}{ }^{+}$channel blocker for cardiac smooth muscles and approved for human use to treat angina, hypertension and cardiac arrhythmias [56]. (Fig. 4E).

Hydroxyibuprofen

2-Hydroxyibuprofen is a metabolite of ibuprofen. Ibuprofen is an anti-inflammatory drug (NSAID) and act as cyclooxygenase-inhibitor [57]. It is also used for symptoms of arthritis, fever, and as an analgesic. Ibuprofen is known to have an antiplatelet effect as well. (Fig. 4F).

\section{Discussion}


Ficus religiosa (L.) plant recently attracted global attention towards its tremendous medicinal properties against various lifestyle diseases and infections. Since cancer is the second leading disease to cause mortality and morbidity worldwide, hence there is urgent need to bring novel and effective treatment in broad sense. Firstly, cytotoxic concentrations were determined for the extract to operate the concentrations for anticancer properties by using SRB assay. Defining $25 \%$ cytotoxicity at the highest concentration of $1000 \mu \mathrm{g} / \mathrm{mL}$ by Trypan Blue method further became easy to select lower concentrations for next SRB assay for investigating anticancer properties. Selection of two in vitro assays in the current work could differentiate the frank cellular toxicity and interruption of cell functions. Due to selection of Trypan Blue assay, it was possible to know the killing properties of the extract and helped in establishing the direct killing concentration [58]. On the other hand, selection of SRB assay in the work successfully determined that at what concentrations, the extract caused disturbances in the cellular functions of the cancer cells mainly during growth and proliferation stages of the cells [59]. Specificity of SRB dye towards protein ultimately determines cellular proliferation, growth of the cells. The Decrease in absorbance of the dye in sample extract directly impacted cell number, growth of individual cell or cell cycle. HR-LCMS analysis of extract showed presence of several pharmacologically active compounds with documented anticancer potential. Mode of action of these compounds could be different but in broad sense of available information it has been found that the effect is through inducing oxidative stress which ultimately causing death of the cancer cells. Selection of highly invasive, commonly causing breast cancer cells, MDA-MB-231gives an advantage of studying the extract for future development of anticancer therapy [60]. Recently it has been investigated that F. religiosa (L.) induced apoptosis in ovarian cancer cell lines Jurkat cancer cells indicates that substance mixture has active chemicals that interferes in anti-apoptotic pathways of cancer cells [61]. Finally, validity of the SRB assay was confirmed by using positive drug Adriamycin at validated concentrations along with the experiment to confirm end point results are as per standard operating conditions of the experiment.

\section{Conclusion}

Concentrations of direct killing effect as well as disruption of cellular processes of MDA-MB-231 were successfully established in the experiment for the extract of $F$. religiosa. Strategy of establishing cell killing concentration by Trypan Blue assay made possible to investigate anti-cancer effect of the extract by operating lower than cytotoxic concentrations in SRB assay. Extract demonstrated $25 \%$ cytotoxicity at the concentration of $1000 \mu \mathrm{g} / \mathrm{mL}$ in Trypan Blue exclusion assay. Secondly, the extract showed biologically significant disruptions of cellular functions in human breast cancer cell line MDA-MB-231 at the concentrations of 100 and $200 \mu \mathrm{g} / \mathrm{mL}$. HR-LCMS analysis data showed presence of number of active compounds which are having various medicinal properties. The identification and analysis of chemically active components in $F$. religiosa leaves extract could be promising remedy in the future to treat human breast cancer particularly caused due to MDA-MB0-231 cells. The work further warrants in-depth chemical identification and fractionation of other unknown anticancer compounds if any present in extract with their in-vitro, and in-vivo anticancer evaluations. 


\section{Abbreviations}

F. religiosa - Ficus religiosa, SRB -Sulforhodamine B, PR- progesterone receptor, DHC - dihydrocoumarin, ADR- standard drug Adriamycin , DMSO - Dimethyl sulphoxide, TCA-Tricholoacetic acid.

\section{Declarations}

\section{Acknowledgments}

Authors are thankful to IIT, Mumbai for evaluating mass spectra for identification of compounds. Authors are equally thankful to ACTREC Mumbai for investigating activity of leaves extract on breast cancer cell line by conducting SRB cell assay.

\section{Author's contributions}

Experiment were designed, performed and wrote by Shaikh. A. Data was analyzed and interpreted by Patel. $M$ and interpreted data on anticancer activity. Shaikh. $A$ and Patel. $M$ and Padul. $M$ reading and correcting the manuscript. All authors read and approved the final manuscript.

\section{Funding}

This study was not supported by any funding.

\section{Availability of data and materials}

No Availability.

\section{Ethics approval and consent to participate}

Not applicable.

\section{Consent to Publish}

Not applicable.

\section{Declaration of competing interest}

The authors declared that they have no competing of interests to this work.

\section{References}

1. Thapliyal A, Khar RK, Chandra A. Overview of Cancer and Medicinal Herbs used for Cancer Therapy. Asian Journal of Pharmaceutics. 2018;12:1-8.

2. Kooti W, Servatyari K, Behzadifar M, et al. Effective Medicinal Plant in Cancer Treatment, Part 2: Review Study. Journal of Evidence-Based Complementary Alternative Medicine. 2017;22:982-95. 
3. Rafieian-Kopaie M, Nasri H. On the occasion of world cancer day 2015; the possibility of cancer prevention or treatment with antioxidants: The ongoing cancer prevention researches. International Journal of Preventive Medicine. 2015;6:108-12.

4. Newman DJ, Cragg GM. Natural products as sources of new drugs over the last 25 years. J Nat Prod. 2007;70:461-77.

5. Mansouri E, Kooti W, Bazvand M, et al. The effect of hydro-alcoholic extract of Foeniculum vulgare mill on leukocytes and hematological tests in male rats. Journal of Natural Pharmaceutical Products. 2015;10:1-5.

6. Makhija IK, Sharma IP, Khamar D. Phytochemistry and Pharmacological properties of Ficus religiosa: an overview. India Annals of Biological Research. 2010;1:171-80.

7. Panda SK, Panda NC, Sahue BK. Effect of tree leaf tannin on dry matter intake by goats. Indian Vet J. 1976;60:660-4.

8. Lansky EP, Paavilainen HM, Pawlus AD, et al. Ficus spp. (fig): ethnobotany and potential as anticancer and anti-inflammatory agents. J Ethnopharm. 2008;119:195-213.

9. Enit BD, Arumugam VA, Palanisamy SK, et al. Phytochemistry and Pharmacology of Ficus religiosa. Sys Rev Pharm. 2018;9(1):45-8.

10. Haneef J, Parvathy M, Thankayyan RSK, et al. Bax Translocation Mediated Mitochondrial Apoptosis and Caspase Dependent Photosensitizing Effect of Ficus religiosa on Cancer Cells. PLoS ONE. 2012;7:1-17.

11. Choudhari AS, Suryavanshi SA, Ingle $\mathrm{H}$, et al. Evaluating the antioxidant potential of aqueous and alcoholic extracts of Ficus religiosa using ORAC assay and assessing their cytotoxic activity in cervical cancer cell lines. Biotechnol Bioinf Bioeng. 2011;1:443-50.

12. Joseph B, Justin S. Phytopharmacological and phytochemical properties of three Ficus Species- an overview. International Journal of Pharma Bio Sciences. 2010;1:246-53.

13. Jain R, Jain SK. Traditional medicinal plants as anticancer agents from Chhattishgarh, India: An overview. International Journal of Phytomedicine. 2010;2:186-96.

14. Purnamasari R, Winarni D, Permanasari A, et al. Anticancer Activity of Methanol Extract of Ficus carica Leaves and Fruits Against Proliferation, Apoptosis, and Necrosis in Huh7it Cells. Cancer Inform. 2019;18:1-7.

15. Carlos AS, Alvarez-Fitz P, Zacapala-Gómez AE, et al. Phytochemical profile and antiproliferative effect of Ficus crocata extracts on triple negative breast cancer cells. BMC Complementary Medicine Therapies. 2020;20:191.

16. Enitome EB, Jennifer M, Edward GR, et al. In Vitro Antiproliferative Effect of Ficus exasperata (Vahl) on Ovarian Cancer Cells -a Preliminary Investigation. Nat Prod Res. 2017;31:2164-8.

17. Liu H, Zang C, Fenner MH, et al. PPAR gamma ligands and ATRA inhibit the invasion of human breast cancer cells in vitro. Breast Cancer Res Treat. 2003;79:63-74. 
18. Chavez KJ, Garimella SV, Lipkowitz S. Triple Negative Breast Cancer Cell Lines: One Tool in the Search for Better Treatment of Triple Negative Breast Cancer. Breast Dis. 2010;32:35-48.

19. Cell Viability. Testing with Trypan Blue Exclusion Method. NIH, USA.

20. Vanicha V, Kanyawim K. Sulforhodamine B colorimetric assay for cytotoxicity screening. Nat Protoc. 2006;1:1112-6.

21. Skehan P, Storeng R, Scudiero D. New colorimetric cytotoxicity assay for anticancer-drug screening. J Natl Cancer Inst. 1990;82:1107-12.

22. Finney DJ. Probit Analysis. 2nd ed. Cambridge: Cambridge University Press; 1952.

23. Shaikh A, Tekale S, Wagh S, et al. Metabolite Profiling of Arginase Inhibitor activity guided fraction of Ficus religiosa leaves by HR-LCMS. Biomedical Chromatography. 2020; e4966.

24. Xie J, Wang C, Gore JC. High throughput screening for colorectal cancer specific compounds. Comb Chem High Throughput Screen. 2016;19:180-8.

25. Kaushik V, Azad N, Yakisich JS, et al. Antitumor effects of naturally occurring cardiac glycosides convallatoxin and peruvoside on human ER + and triplenegative breast cancers. Cell Death Discov. 2017;3:17001-9.

26. Kaushik V, Yakisich JS, Azad N, et al. nti-tumor effects of cardiac glycosides on human lung cancer cells and lung tumorspheres. J Cell Physiol. 2016;232:2497-507.

27. Anderson SE, Barton CE. The cardiac glycoside convallatoxin inhibits the growth of colorectal cancer cells in a p53-independent manner. Molecular Genetics Metabolism Reports. 2017;13:42-5.

28. Ofentse M. Umbelliferone. Sources, chemistry and bioactivities review. Bulletin of Faculty of Pharmacy. 2017;55:223-32.

29. Hoult JRS, Paya M. Pharmacological and biochemical actions of simple coumarins: natural products with therapeutic potential. General Pharmacology: The Vascular System. 1996;27:713-22.

30. Leal LKAM, Ferreira AAG, Bezerra GA, et al. Antiinociceptive, anti-inflammatory and bronchodilator activities of Brazilian medicinal plants containing coumarin: a comparative study. $J$ Ethnopharmacol. 2000;70:151-9.

31. Vasconcelos JF, Teixeira MM, Barbosa-Filho JM, et al. Effects of umbelliferone in a murine model of allergic airway inflammation. Eur J Pharmacol. 2009;609:126-31.

32. Ramesh B, Pugalendi KV. Antioxidant role of umbelliferone in STZ-diabetic rats. Life Sci. 2006;79:306-10.

33. Kofinas C, Chinou L, Loukis A, et al. Cytotoxic coumarins from the aqueous parts of Terdyliim apulum and their effects on non-small cell bronchial carcinoma cell lines. Planta Med. 1998;64:1746.

34. Ramu R, Shirahatti PS, Zameer F, et al. Inhibitory effect of banana (Musa sp. var. Nanjangud rasa bale) flower extract and its constituents Umbelliferone and Lupeol on a-glucosidase, aldose reductase and glycation at multiple stages. S Afr J Bot. 2014;95:54-63. 
35. Hyun SK, Oh YN, Kwon HJ, et al. Angiotensin converting enzyme inhibitory benzopyranoids from Angelica gigas. Food Sci Biotechnol. 2013;22:1741-5.

36. Rauf $\mathrm{A}$, Khan $\mathrm{R}$, Khan $\mathrm{H}$, et al. In vivo antinociceptive and antiinflammatory activities of umbelliferone isolated from Potentilla evestita. Nat Prod Res. 2014;28:1371-4.

37. Jurd L, King AD, Mihara K. Antimicrobial properties of umbelliferone derivatives. Phytochemistry. 1971;10:2965-70.

38. Subramaniam SR, Ellis EM. Neuroprotective effects of umbelliferone and esculetin in a mouse model of Parkinson's. J Neurosci Res. 2013;3:453-61.

39. Ramesh B, Pugalendi KV. Impact of umbelliferone (7-hydroxycoumarin) on hepatic marker enzymes in streptozotocin diabetic rats. Indian J Pharmacol. 2006;38:209-10.

40. Muthu R, Selvaraj N, Vaiyapuri M. Anti-inflammatory and proapoptotic effects of umbelliferone in colon carcinogenesis. Hum Exp Toxicol. 2016;35:1041-54.

41. Zaneta NC, Liang X, Zengjian H, et al. Discovery of Embelin as a Cell-Permeable, Small-Molecular Weight Inhibitor of XIAP through Structure-Based Computational Screening of a Traditional Herbal Medicine Three-Dimensional Structure Database. Med Chem. 2004;47:2430-40.

42. Radhakrishnan N, Gnanamani A, Prasad NR, et al. Inhibition of UVB-induced oxidative damage and apoptotic biochemical changes in human lymphocytes by 2, 5-dihydroxy-3-undecyl-1, 4benzoquinone (embelin). Int J Radiat Biol. 2012;88:575-82.

43. Thippeswamy BS, Nagakannan P, Shivasharan BD, et al. Protective effect of embelin from Embelia ribes Burm. against transient global ischemia-induced brain damage in rats. Neurotox Res. 2011;20:379-86.

44. Pathan SA, Iqbal Z, Zaidi SM, et al. CNS drug delivery systems: novel approaches, Recent Pat. Drug Deliv Formul. 2009;3:71-89.

45. Vaz WF, Custodio JMF, Rodrigues NMN, et al. A novel dihydrocoumarin under experimental and theoretical characterization. J Mol Model. 2017;23:1-13.

46. Jacobi JL, XuLi B, Menze AK, et al. Impacts on Sirtuin Function and Bioavailability of the Dietary Bioactive Compound Dihydrocoumarin. Plosone. 2016;1:1-27.

47. Zhang K, Ding W, Sun J, et al. Antioxidant and antitumor activites of 4- acryloumarins and 4- acryl-3, 4-dihyrocoumins. Biochimie. 2014;107:203-10.

48. Posakony J, Hirao M, Sam Stevens S, Simon JA, Bedalov A. Inhibitors of Sir2: Evaluation of Splitomicin Analogues. J Med Chem. 2004;47:2635-44.

49. linuma M, Tanaka T, Mizuno M, et al. Stucture-activity correlation of flavonoids for inhibition of bovine lens aldose reductase. Chem Pharm Bull. 1989;37:1813-5.

50. Hsu FL, Nonaka GI, Nishioka I. Tannins and related compounds. XXXI. Isolation and characterization of proanthocyanidins in kandelia candel (L.) DRUCE. Chem Pharm Bull. 1985;33:3142-52.

51. Adams TB, Greer DB, Doull J, et al. The FEMA GRAS assessment of lactones used as flavour ingredients. Food Chem Toxicol. 1998;36:249-78. 
52. Asai F, linuma M, Tanaka T, et al. Two Complex Flavonoids in the Farinose Exudate of Pityrogramma calomelanos. Heterocycles. 1992; 33: 229-237.

53. Hoeven VD, Cho KJ, Ma X, et al. Fendiline inhibits K-Ras plasma membrane localization and blocks K-Ras signal transmission. Molecular cellular biology. 2013;33:237-51.

54. Voigt RM, Riddle JL, Napier TC. Effect of fendiline on the maintenance and expression of methamphetamine-induced conditioned place preference in Sprague-Dawley rats. Psychopharmacology. 2014;231:2019-29.

55. Bayer R, Mannhold R. Fendiline: a review of its basic pharmacological and clinical properties. Pharmatherapeutica. 1986;5:103-36.

56. Woods N, Trevino J, Coppola D, et al. Fendiline inhibits proliferation and invasion of pancreatic cancer cells by interfering with ADAM10 activation and $\beta$-catenin signalling. Oncotarget. 2015;6:35931-48.

57. Neunzig I, Gohring A, Dragan C, et al. Production and NMR analysis of the human ibuprofen metabolite 3- Hydroxyibuprofen. J Biotechnol. 2012;157:417-20.

58. Esteban AO, Andrea LK. Sulforhodamine B (SRB) Assay in Cell Culture to Investigate Cell Proliferation. Bio Protoc. 2016; 6:1-9.

59. Holiday DL, Speirs V. Choosing the right cell line for breast cancer research. Breast Cancer Res. 2011;13:1-7.

60. Maity A, Bisoi PC, Das AB, Maiti P, Senapati MR. Cytotoxicity study of F. religiosa leaf extract against jurkat cells line. Anim Med Res. 2017;7:18-21.

61. Andreia P, Megan B, Puffy S, Zeno A. Anti-proliferative properties of commercial Pelargonium sidoides tincture, with cell-cycle G0/G1 arrest and apoptosis in Jurkat leukaemia cells. Pharm Biol. 2016;54:1831-18s40.

\section{Tables}

\section{Table 1}

Active compounds identified by LC-HRMS from extract of Ficus religiosa leaves 


\begin{tabular}{|lllll|}
\hline Compound Label & RT & Mass & Formula & DB Diff (ppm) \\
\hline Fendiline & 6.561 & 315.205 & $\mathrm{C}_{23} \mathrm{H}_{25} \mathrm{~N}$ & -19.86 \\
\hline Convallatoxin & 13.556 & 550.2647 & $\mathrm{C}_{29} \mathrm{H}_{42} \mathrm{O}_{10}$ & 23.81 \\
\hline Umbelliferone & 14.114 & 162.0323 & $\mathrm{C}_{9} \mathrm{H}_{6} \mathrm{O}_{3}$ & -3.51 \\
\hline Hydroxyibuprofen & 15.15 & 222.1261 & $\mathrm{C}_{13} \mathrm{H}_{18} \mathrm{O}_{3}$ & -2.1 \\
\hline Embelin & 15.862 & 294.1842 & $\mathrm{C}_{17} \mathrm{H}_{26} \mathrm{O}_{4}$ & -3.64 \\
\hline Dihydrocoumarin & 15.903 & 148.053 & $\mathrm{C}_{9} \mathrm{H}_{8} \mathrm{O}_{2}$ & -3.81 \\
\hline
\end{tabular}

\section{Table 2}

In vitro cytotoxicity testing of $F$. religiosa leaf extract by trypan blue assay on MB-MD-231 cell lines

\begin{tabular}{|llllll|}
\hline Experiment & \multicolumn{5}{c|}{$\%$ viable cells at respective concentrations $(\mu \mathrm{g} / \mathrm{mL})$} \\
\cline { 2 - 6 } & 0 & 125 & 250 & 500 & 1000 \\
\hline Experiment 1 & 95 & 94 & 89 & 75 & 69 \\
\hline Experiment 2 & 98 & 94 & 95 & 80 & 70 \\
\hline Experiment 3 & 96 & 96 & 92 & 73 & 57 \\
\hline Mean & 96.33 & 94.67 & 92 & 76 & 65.33 \\
\hline SSD & 1.53 & 1.15 & 3 & 3.61 & 7.23 \\
\hline
\end{tabular}

\section{Table 3}

Concentrations used in in vitro anticancer experiment of MB-MD-231 cell lines

\begin{tabular}{|lcccc|}
\hline substance & \multicolumn{4}{c|}{ Concentrations $(\mu \mathrm{g} / \mathrm{mL})$} \\
\cline { 2 - 5 } & 1 & 2 & 3 & 4 \\
\hline Sample & 25 & 50 & 100 & 200 \\
ADR & 10 & 20 & 40 & 80 \\
\hline
\end{tabular}


ADR = Adriamycin (an anticancer drug used as positive control)

\section{Table 4}

In vitro anticancer activity of $F$. religiosa leaves extract in MDA-MB-231 breast cancer cell lines by using SRB assay.

\begin{tabular}{|lllllllll|}
\hline Substance & \multicolumn{6}{c|}{ \% Control growth at respective concentrations $(\mu \mathrm{g} / \mathrm{ml})$} \\
& \multicolumn{3}{c}{ Sample $(\mu \mathrm{g} / \mathrm{mL})$} & \multicolumn{5}{c|}{ Adriamycin $(\mu \mathrm{g} / \mathrm{mL})$} \\
\cline { 2 - 10 } & $\mathbf{2 5}$ & $\mathbf{5 0}$ & $\mathbf{1 0 0}$ & $\mathbf{2 0 0}$ & $\mathbf{1 0}$ & $\mathbf{2 0}$ & $\mathbf{4 0}$ & $\mathbf{8 0}$ \\
\hline Experiment 1 & 97.1 & 96.2 & 70.1 & 19.6 & -43.7 & -54.1 & -61.9 & -40.6 \\
\hline Experiment 2 & 103.4 & 97.9 & 74.9 & 25.5 & -43.6 & -53.5 & -58.7 & -42.2 \\
\hline Experiment 3 & 97.9 & 93.6 & 74.4 & 19.5 & -47.2 & -54.0 & -64.7 & -43.9 \\
\hline Total & 298.3 & 287.7 & 219.4 & 64.5 & -134.6 & -161.6 & -185.4 & -126.7 \\
\hline Mean & 99.4 & 95.9 & 73.1 & 21.5 & -44.9 & -53.9 & -61.8 & -42.2 \\
\hline 士SD & 3.4 & 2.1 & 2.6 & 3.4 & 2.0 & 0.3 & 3.0 & 1.6 \\
\hline
\end{tabular}

\section{Table 5}

Cytotoxicity and cell growth inhibition parameters

\begin{tabular}{|lllc|}
\hline Substance & \multicolumn{3}{l}{ Concentrations $(\mu \mathrm{g} / \mathrm{ml})$} \\
\cline { 2 - 4 } & $\mathrm{LC}_{50}$ & $\mathrm{TGI}$ & $\mathrm{GI}_{50}$ \\
Sample & 180.0 & 120 & 70 \\
ADR & 46.2 & $<10$ & $<10$ \\
\hline
\end{tabular}

$\mathrm{LC}_{50}=$ Concentration of drug causing $50 \%$ cell kill.

$\mathrm{GI}_{50}=$ Concentration of drug causing $50 \%$ inhibition of cell growth

$\mathrm{TGI}=$ Concentration of drug causing total inhibition of cell growth

$\mathrm{ADR}=$ Adriamycin, Positive control compound 


\section{Figures}

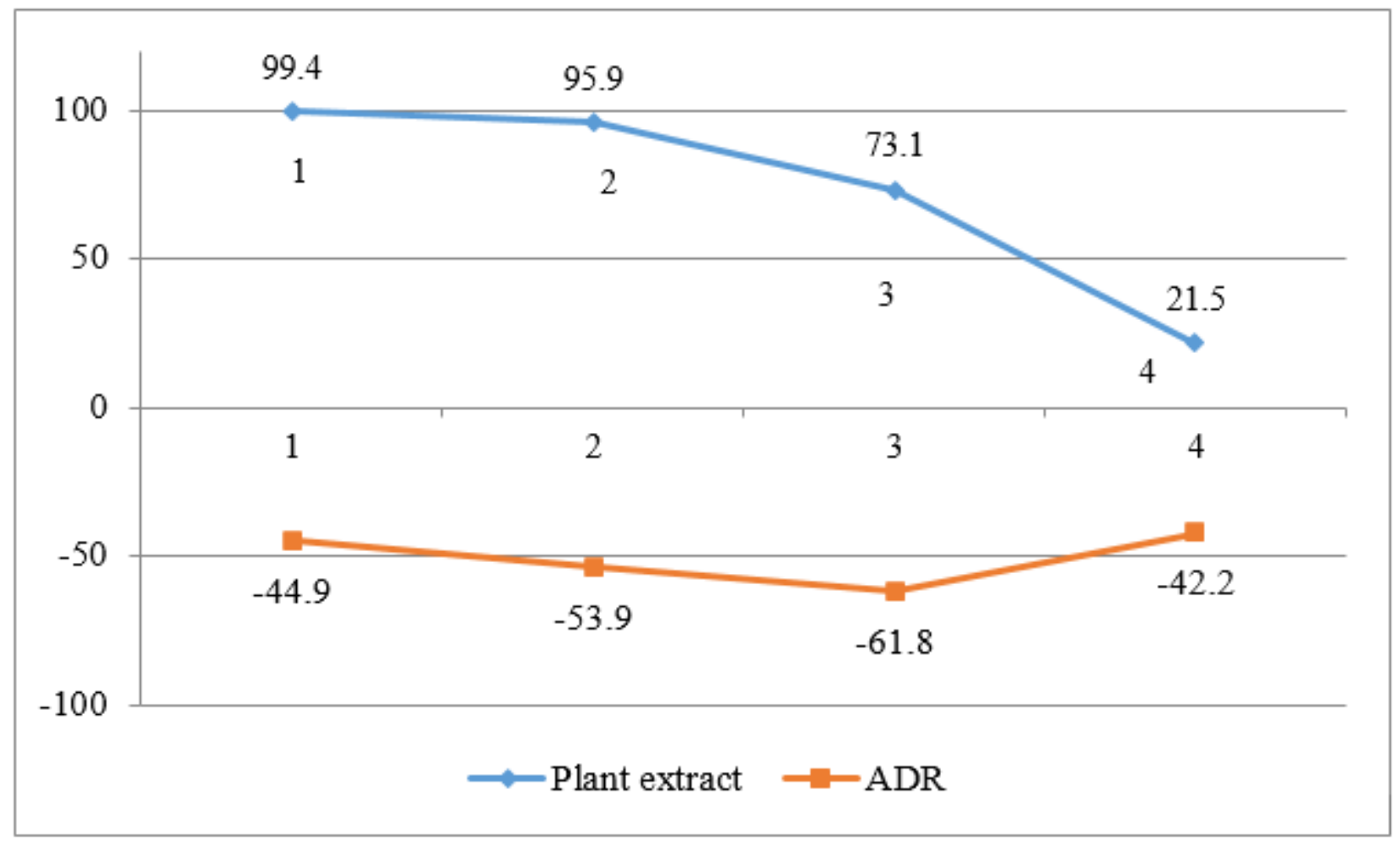

\section{Figure 1}

Average \% control growth of cells when incubated with plant extract and standard drug Adriamycin.

(Plant extract: $1=62.5 \mu \mathrm{g} / \mathrm{ml}, 2=125 \mu \mathrm{g} / \mathrm{ml} ; 3=250 \mu \mathrm{g} / \mathrm{ml} ; 4=500 \mu \mathrm{g} / \mathrm{ml}$ ADR: $1=10 \mu \mathrm{g} / \mathrm{ml}, 2=20$ $\mu \mathrm{g} / \mathrm{ml} ; 3=40 \mu \mathrm{g} / \mathrm{ml} ; 4=80 \mu \mathrm{g} / \mathrm{ml}$.) 


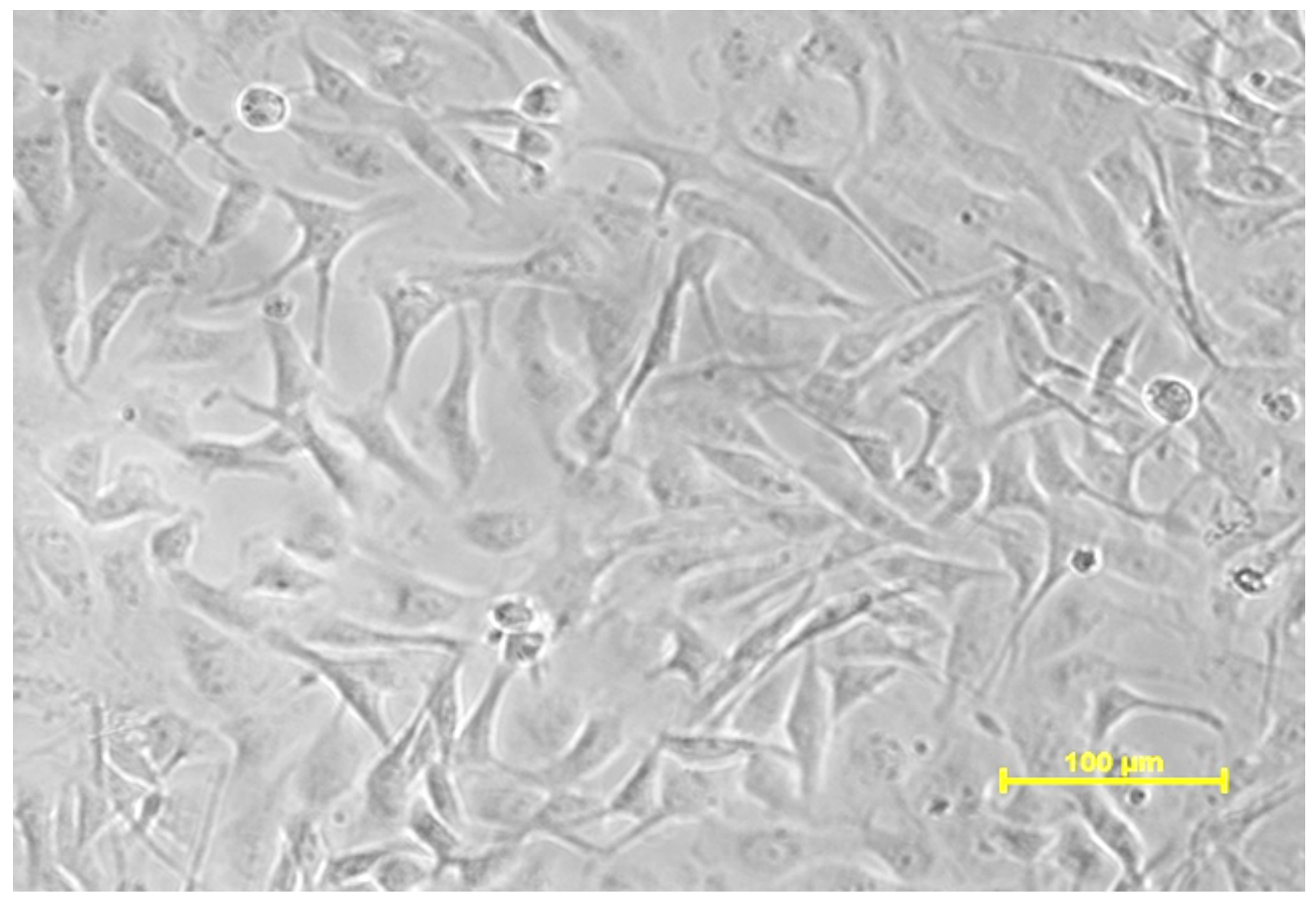

Figure 2

Cell growth after 48 hours of incubation of control sample (Concentration: $0 \mu \mathrm{g} / \mathrm{mL}$ ), MDA-MB-231 breast cancer cell line in phase contrast microscopy. 


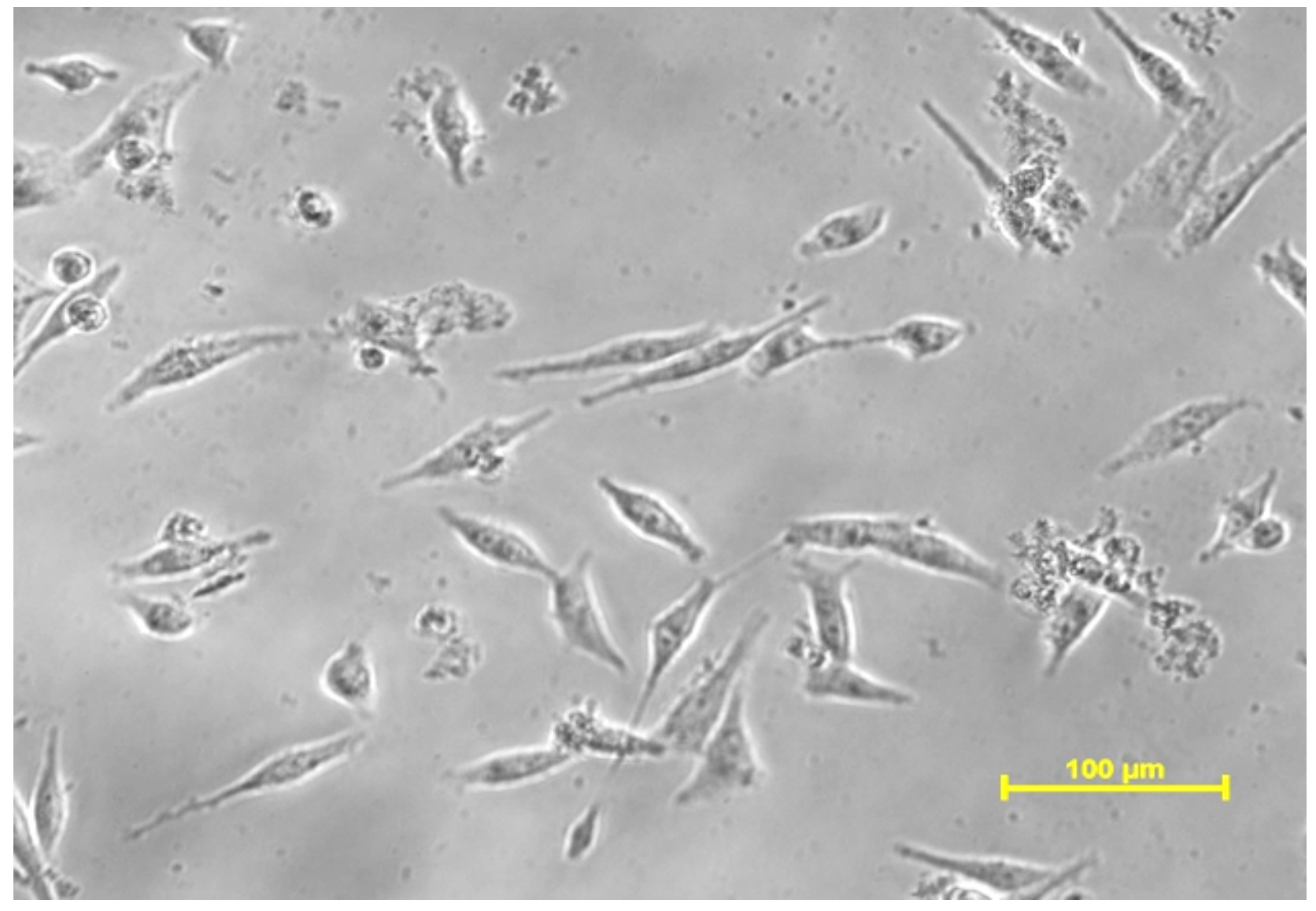

\section{Figure 3}

Cell growth after 48 hours of incubation of leaf extract (Concentration: $500 \mu \mathrm{g} / \mathrm{mL}$ ), MDA-MB-231 breast cancer cell line in phase contrast microscopy. 


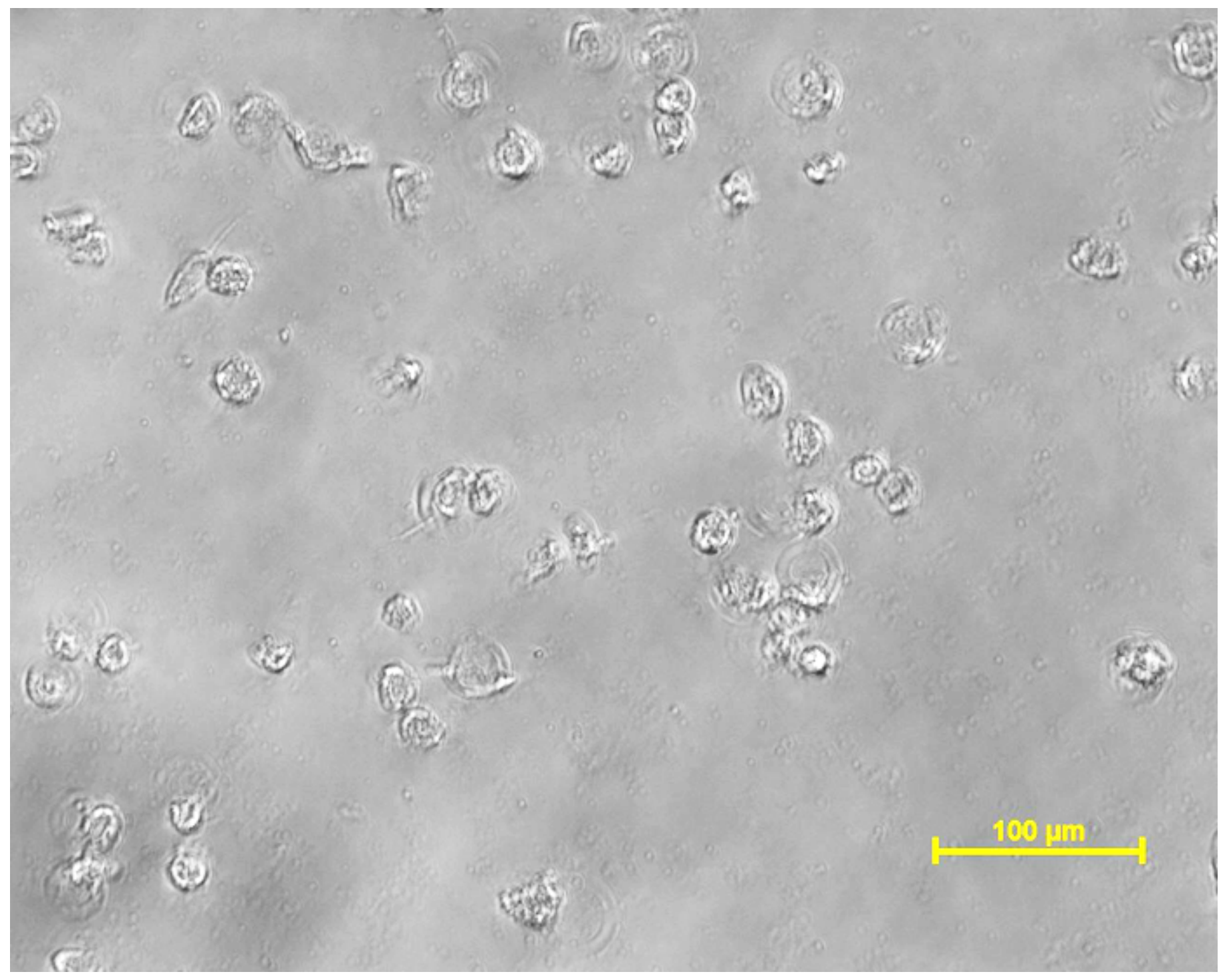

\section{Figure 4}

Cell growth after 48 hours of incubation of standard drug Adriamycin (Concentration: $80 \mu \mathrm{g} / \mathrm{mL}$ ) MDAMB-231 breast cancer cell line in phase contrast microscopy 


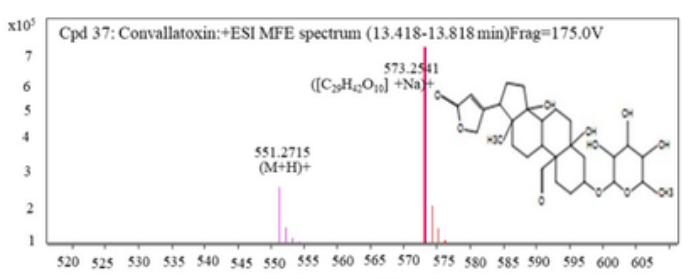

Count vs. Mass to Charge ( $\mathrm{m} / \mathrm{z})$

(A) Convallatoxin

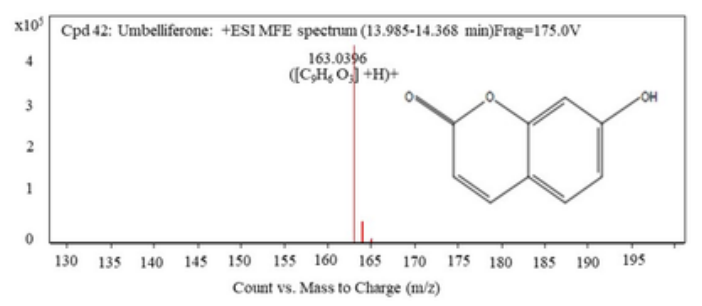

(B) Umbelliferone

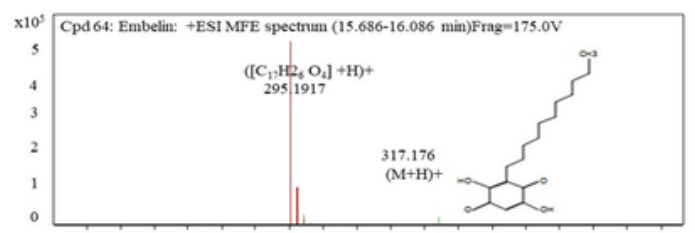

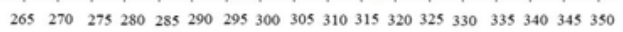

Count vs. Mass to Charge (m/z)

(C) Embelin

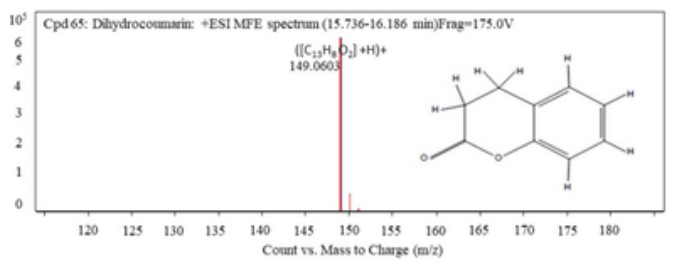

(D) Dihydrocoumarin
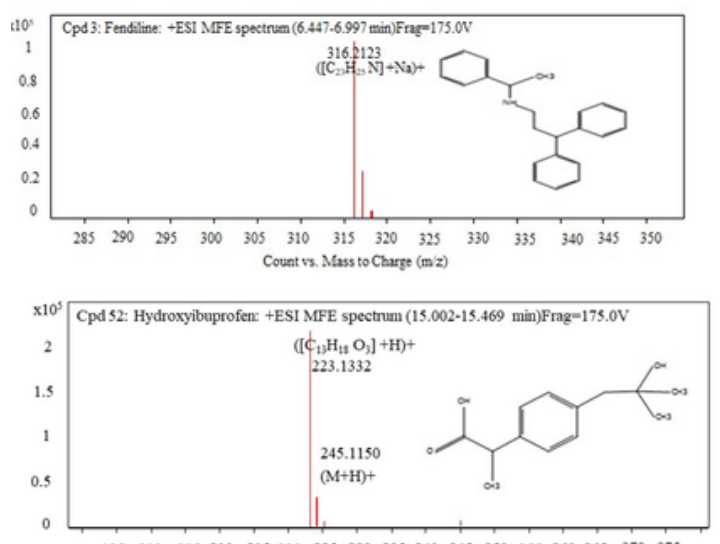

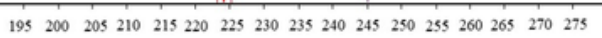

Count vs. Mass to Charge ( $\mathrm{m} / 2)$

(F) Hydroxyibuprofen

\section{Figure 5}

Phytochemicals identification of F. religiosa by HR-LCMS. 